\author{
Błażej Osowski \\ Uniwersytet im. Adama Mickiewicza w Poznaniu \\ Instytut Filologii Polskiej \\ ORCID 0000-0002-4226-1378; e-mail: blazej.osowski@amu.edu.pl
}

\title{
Między wyjątkowością a wstydem. Świadomość językowa mieszkańców powiatu ostrowskiego
}

\begin{abstract}
Abstrakt: W artykule zajęto się zagadnieniami związanymi ze świadomością językową. Celem tekstu jest przedstawienie, co mieszkańcy powiatu ostrowskiego sądzą o gwarach. Materiał pozyskano za pomocą ankiety internetowej. Analiza porusza kilka kwestii: występowanie gwar w okolicach Ostrowa Wielkopolskiego, zauważane cechy gwar, skojarzenia wywołane przez słowo „gwara” (potoczny stereotyp gwary), geografia gwar w świadomości ankietowanych, stosunek do gwary, pokoleniowe występowanie gwary.
\end{abstract}

Słowa kluczowe: świadomość językowa, gwara, Wielkopolska, metoda ankietowa

\begin{abstract}
Between uniqueness and shame. Language awareness of the inhabitants of the Ostrów Wielkopolski powiat. The article presents issues related to language awareness. The purpose of the text is to present the opinions of residents of Ostrów Wielkopolski powiat about dialects. The material was obtained by means of an online survey. The analysis raises several issues: the occurrence of dialects around Ostrów Wielkopolski, the identified features of dialects, associations evoked by the word "dialect" (the dialect stereotype), the geography of dialects as perceived by the respondents, attitude to dialects, generational occurrence of dialects.
\end{abstract}

Keywords: Metalinguistic awareness, dialect, Greater Poland, survey method

\section{Wstęp}

Powiat ostrowski leży w południowo-zachodniej części województwa wielkopolskiego, a jego stolicą jest Ostrów Wielkopolski ${ }^{1}$. Historia tego powiatu zaczyna się dopiero w 1887 roku. Wcześniej jego ziemie stanowiły część powiatu kaliskiego (do rozbiorów) lub odolanowskiego (1807-1887)². O gwarach powiatu ostrowskiego można mówić ze względu na istnienie ośrodka administracyjnego, kulturalnego i gospodarczego w Ostrowie, który oddziaływał na okoliczną ludność. Z dialektologicznego

\footnotetext{
1 Wymiennie, skrótowo używam też określenia Ostrów. Jeśli będzie mowa o powiecie, to mam na myśli powiat ostrowski.

2 https://pl.wikipedia.org/wiki/Powiat_ostrowski_(wojew\%C3\%B3dztwo_wielkopolskie)\#Historia [dostęp 3.11.2019].
} 
punktu widzenia tereny powiatu nie stanowią zwartego obszaru gwarowego. W zależności od koncepcji badawczej ziemie te klasyfikowano jako: Kaliskie (Nitsch 1968, 195), Wielkopolska środkowa (Urbańczyk 1962, m. 3) czy Wielkopolska wschodnia (Sobierajski 2001, 68). Gwary powiatu są wewnętrznie zróżnicowane, a granicę wyznacza Barycz, która aż do połowy XIX w. stanowiła naturalną przeszkodę między Wielkopolską a terenami na południe od rzeki utrzymującymi łączność z macierzystą dzielnicą - Śląskiem (Nowak, Skoczylas-Stawska 1990, 645).

Celem niniejszego tekstu jest przedstawienie, co mieszkańcy powiatu ostrowskiego sądzą o gwarach. Będzie zatem mowa nie o ustaleniach badaczy, lecz o świadomości językowej (wiedzy jawnej i niejawnej) mieszkańców wspomnianego terenu.

Świadomość językowa to „ogół sądów o języku i poglądów na język charakterystycznych dla jakiejś osoby lub grupy społecznej. Te sądy i poglądy mogą mieć charakter intuicyjny i nie tworzyć spójnego systemu, ale mogą też być umotywowane i podbudowane wiedzą o języku. W każdym wypadku muszą one być względnie trwałe i powinny oddziaływać na zachowanie językowe osoby czy grupy ludzi" (Markowski 2006, 1680). Ze świadomością językową łączą się postawy wobec języka. Pojęcie świadomości językowej odnieść można do gwary jako terytorialnej odmiany języka polskiego i osób nią się posługujących lub mających z nią kontakt, co też już wielokrotnie czyniono (np. Cygan 2011; Kąś 1994; Kucała 1960; Kucharzyk 2002, 2011; Kurek 1995; Pawłowski 1967; Piotrowicz, Witaszek-Samborska 2009, 21-27)3. W ten właśnie nurt badawczy wpisuje się niniejszy artykuł.

Dla zebrania danych posłużyła internetowa ankieta (https://docs.google.com/forms/d/e/1FAIpQLSfj0D3CkVbU6QasEqj8iaY43udP-JwdvmlPrWXLRwCgZQCs3Q/ viewform?usp=sf_link), w której można było wziąć udział między wrześniem 2018 roku a październikiem 2019 roku. Przesłano 50 wypełnionych formularzy.

Formularz składał się z trzech części. W pierwszej znajdowały się pytania odnoszące się do świadomości językowej, w drugiej - sprawdzające znajomość słownictwa gwarowego, w trzeciej - dane socjologiczne respondentów. Ze względu na temat niniejszego tekstu skupię się na informacjach pozyskanych w pierwszej części ankiety.

\section{Występowanie gwary w okolicach Ostrowa Wielkopolskiego}

Dwa pierwsze pytania (Czy Twoim zdaniem w okolicach Ostrowa używa się gwary? Jeśli tak, prosze wpisać w pole „Inne” - gdzie jej się używa?, Czy Twoim zdaniem gwary używa się w samym Ostrowie?) dostarczyć miały rozeznania, czy zdaniem ankietowanych w ich najbliższej okolicy występują gwary wiejskie lub miejska (Ostrowa). $\mathrm{Na}$ pierwsze pytanie blisko $3 / 4$ ankietowanych odpowiedziało pozytywnie (dokładne dane por. tabela 1). W pytaniu o gwarę miejską Ostrowa przeważały odpowiedzi negatywne (52\%). Często podawano także, gdzie z gwarą można się zetknąć. Padały zatem nazwy konkretnych miejscowości w powiecie ostrowskim - wsi (Garki, Kocina, Nabyszyce, Raczyce, Świeca), ale i miast (Odolanów, Ostrów), jak

\footnotetext{
${ }^{3}$ O hiperyzmach związanych ze świadomością językową i zjawiskami gwarowymi przeczytać można w: Osowski 2019.
} 
Tabela 1. Świadomość istnienia gwary wśród ankietowanych z i spoza powiatu ostrowskiego

\begin{tabular}{|c|c|c|c|c|c|}
\hline \multirow{2}{*}{$\begin{array}{c}\text { Grupa } \\
\text { ankietowanych }\end{array}$} & \multirow{2}{*}{$\begin{array}{l}\text { Liczba } \\
\text { ankietowanych }\end{array}$} & \multicolumn{2}{|c|}{$\begin{array}{c}\text { Czy Twoim zdaniem w okolicach } \\
\text { Ostrowa używa sie gwary?... }\end{array}$} & \multicolumn{2}{|c|}{$\begin{array}{c}\text { Czy Twoim zdaniem gwary } \\
\text { uzywa się } w \text { samym Ostrowie? }\end{array}$} \\
\hline & & TAK w $\%$ & NIE w \% & TAK w $\%$ & NIE w \% \\
\hline Wszyscy & 50 & 72,00 & 28,00 & 45,00 & 52,00 \\
\hline $\begin{array}{l}\text { Mieszkańcy } \\
\text { Ostrowa }\end{array}$ & 10 & 40,00 & 60,00 & 40,00 & 60,00 \\
\hline $\begin{array}{l}\text { Mieszkańcy } \\
\text { powiatu } \\
\text { ostrowskiego }\end{array}$ & 30 & 76,67 & 23,33 & 43,33 & 56,70 \\
\hline $\begin{array}{l}\text { Ankietowani } \\
\text { spoza powiatu } \\
\text { ostrowskiego }\end{array}$ & 10 & 90,00 & 10,00 & 70,00 & 30,00 \\
\hline
\end{tabular}

i ogólniejsze sformułowania typu: $\mathrm{Na}$ wsi; Zarówno $w$ mieście [Ostrowie - B.O.], jak $i w$ miejscowościach ościennych; na wsi bardziej, ale część słów gwarowych też $w$ Ostrowie i mniejszych miastach; wioski, np. w Gminie Odolanów i Sośnie (w mieście tylko osoby pohodzace ze wsi, ale rzadko, bo się wstydza $)^{4}$. Znamienna jest ostatnia z wypowiedzi, gdzie obok charakterystyki geograficznej pojawia się też socjologiczna. Dostrzec ją można także u innych ankietowanych: Głównie na wsiach $i$ w przypadku ludzi pracujacych fizycznie; Niektóży starsi ludzie; W domach rodzinnych. W świetle powyższych odpowiedzi gwara jawi się przede wszystkim jako odmiana ludowa, o wiele rzadziej miejska (niekiedy dostrzega się podobieństwa leksykalne między nimi), mowa osób niewykształconych (pracujących fizycznie), starszych i środowiska rodzinnego.

Przy analizie dwóch pierwszych pytań warto uwzględnić miejsce zamieszkania, ponieważ czynnik ten ukazuje dane w nowej perspektywie. Mieszkańcy Ostrowa Wielkopolskiego nie dostrzegają gwary ani w swoim mieście, ani w innych miejscowościach powiatu. Mieszkańcy pozostałych miejscowości w powiecie w zdecydowanej większości zauważają istnienie gwar poza Ostrowem, w mniejszej mierze - w tymże mieście. Być może działa tu czynnik miasta - stereotypowo ocenianego jako lepsze niż wieś i postrzeganego jako miejsce, w którym używa się polszczyzny ogólnej. Dopiero ankietowani spoza powiatu (którzy dawniej mieszkali w powiecie, a następnie się z niego wyprowadzili, lub odwrotnie, którzy sprowadzili się do niego z innych zakątków Polski), mając możliwość porównania z mową innych regionów, na oba pytania odpowiadają zdecydowanie pozytywnie. Ponownie jednak odpowiedzi tak więcej jest w grupie pytań o gwary ludowe.

\footnotetext{
${ }^{4}$ Cytaty przytaczam w postaci oryginalnej.
} 


\section{Cechy gwar w okolicach Ostrowa Wielkopolskiego}

Pytanie trzecie (Wymień przykłady z gwary Ostrowa lub okolic [wyrazy, powiedzonka, inne cechy językowe]) i czwarte (Wymień przyklady z gwary ostrowskiej [rozumianej jako gwara charakterystyczna tylko dla Ostrowa i okolic, odmienna od innych gwar]) omawiam łącznie, ponieważ, jak już wspomniałem, odsetek odpowiedzi opowiadających się za istnieniem specyficznej gwary ostrowskiej był niski. Ponadto przykłady wymieniane w odpowiedziach na oba pytania często były zbieżne. Należy zaznaczyć, że odpowiedź na dwa powyższe pytania nie była obligatoryjna i część osób z tego skorzystała. Pojawiło się zatem 30 odpowiedzi z przykładami (jednowyrazowymi, wielowyrazowymi i bardziej rozbudowanymi komentarzami) na pytanie trzecie i tylko 10 - na czwarte.

Wśród odpowiedzi pojawiają się przede wszystkim przykłady leksykalne, wśród których sporą grupę stanowią powszechnie znane i używane regionalizmy, np. warzecha (drewniana łyżka), plendze (placki ziemniaczane), krychać ziemniaki (zamiast dusic ziemniaki); tytka 'torebka, najczęściej papierowa', pyrki; pyry; gzika - twaróg ze szczypiorkiem; laczki (laćki); „Zakluczać” drzwi 'zamykać'; zjeść skibke chleba 'kawałek'; wygogolony 'porozpinany, z odsłoniętym ciałem'; „pudymy na szage bydzie rychlij" 'skrótem, po przekątnej'; ćmik 'papieros'; szagówki 'kopytka'; haczka 'przyrząd do plewienia chwastów'; giry, giery, giyry 'nogi'); rzadziej natomiast przytaczano dialektyzmy, np. Uliczka = furtka, sipa = topata; wrota-brama; jucha 'krew, najczęściej zwierzęca'; kasta, brecha; aby coś sprawdze (zamiast tylko coś srawdze); rajka; giskanka; szrank; baloty. Mała liczba dialektyzmów związana jest zapewne z ich odniesieniem do realiów wiejskich, z którymi nie każdy miał styczność (nawet pomimo mieszkania na wsi - por. Sierociuk 2007, 328-329 - struktura zawodowa zmierzająca do coraz większej dyferencjacji oraz przechodzenia do zajęć pozarolnicznych. Tu też znajduje się słownictwo charakterystyczne tylko dla Ostrowa Wielkopolskiego i okolic, np. Ścionka: pójść sicionka 'pójść skrótem', Idziemy na Ślask (Raszkowska) 'na blokowiska przy ul. Raszkowskiej'; luga 'ostry deszcz, ulewa', lugać; smole to! 'olewam to, pier...olę to's.

W odpowiedziach wymieniano także jednostki potoczne, które ankietowani odbierają jako gwarowe ze względu na ich przynależność do odmian substandardowych polszczyzny. Np. wleźć 'wejść'; wyro 'łóźko'; bajzel 'bałagan'; bryle 'okulary'; bety (pościel, poduszki); ciuchcia 'pociąg'. Należy zaznaczyć, że problem z rozróżnieniem cech regionalnych i potocznych mają także badacze. Oddziaływanie mass mediów (w tym regionalnych), migracje ludności (ze wsi do miasta, z miasta do wsi i z regionu do regionu) oraz względy marketingowe (wykorzystywanie gwary jako elementu reklam) powodują, że do słownictwa polszczyzny ogólnej przenikają wyrazy o ograniczonym zasięgu geograficznym, przez co tym samym zmienia się ich kwalifikacja (Piotrowicz, Witaszek-Samborska 2009, 125).

Ankietowani wymieniali również przykłady zjawisk fonetycznych, np. uproszczenia grup spółgłoskowych (paczalam (zamiast patrzyłam); Se (sobie)), podwyższenia artykulacji samogłosek (często zamiast o mówi się „ło” lub zamiasto o „, u” (np. ton, kuń);

\footnotetext{
${ }^{5}$ Za konsultację znaczeń ostrowianizmów dziękuję dr Justynie Kociembie-Żulickiej.
} 
jo tyż; godom; czymy - czemu), zmiany barwy samogłosek (bechory), labializacje (łogień; łe tam!; uOstrów, uOdolanów, uOstrzeszów). Zdarzyła się nawet uwaga odnośnie do środków prozodycznych: Charakterystyczny akcent.

Do cech fleksyjnych zaliczyć można analityczne formy czasu przeszłego (jo żym bot-ja bytem; forma „,my byli/zrobili” itp. [zamiast byliśmy/zrobiliśmy]) oraz zwrócenie uwagi na różnicę rodzajową nazwy białego sera z przyprawami: pyry z gzika (a nie jak w Poznaniu $-z$ gzikiem).

Jedynym przykładem z gwarową cechą słowotwórczą jest forma mączyty.

Wśród cech składniowych wymienić można zwroty w funkcji fatycznej (No ej!; mosz tej) oraz odmienną łączliwość przyimkową (ide do góry [zamiast ide na góre]; jechać na-jechać do).

Przedstawiona reprezentacja poszczególnych poziomów języka odpowiada w przybliżeniu opisom językoznawczym, tj. najwięcej uwagi poświęca się fonetyce i leksyce, mniej przykładów podaje się z zakresu fleksji, słowotwórstwa czy składni. Znamienne, że choć wymienione cechy były wskazywane przez badaczy gwar omawianego terenu, to w odpowiedziach ankietowanych zabrakło tych, które językoznawcy uznawali za charakterystyczne, tj. mazurzenia w części południowej, przejścia $-c h>-k$, antycypacji miękkości (np. nojsić), zmiękczenia w typie malinia, zwężenia w końcówce -ego > -egó, dyftongicznego yj (Nowak, Skoczylas-Stawska 1990, 645 i n.).

Przy okazji pytania trzeciego i czwartego padały też odpowiedzi o charakterze ogólniejszym, dowodzące świadomości metajęzykowej, pewnego namysłu nad mową swojego, jak i innych regionów, np.: Wychodzenie na dwór, na poludniu gadaja że na pole...; Wydaje mi się że sa to elementy wspólne z gwarami śląskimi, słowa typu „,bania” czy „pierona”, być może również pewne cechy fonetyczne; Nie wiem, czy przykłady powyżej to gwara wielkopolska czy tylko ostrowska. Dobór przykładów ujawnił nasycenie słownictwa okolic Ostrowa germanizmami: szlaka (żuzel jako sport), waga (poziomica); laczki; haczka; kasta; brecha; plendze, choć niedalekie sąsiedztwo w przeszłości zaborowej granicy prusko-rosyjskiej sprawia, że pojawił się także rusycyzm: kniga (książka).

\section{Skojarzenia z gwarą}

W pytaniu szóstym (Wymień do 5 przymiotników, które Twoim zdaniem najlepiej charakteryzuja GWARĘ) i siódmym ( $Z$ czym Ci się kojarzy GWARA? [Do 5 skojarzeń]) badano skojarzenia ze słowem gwara, dlatego oba pytania zostaną omówione łącznie. Na szóste pytanie odpowiedzi udzieliło 22 ankietowanych, a na siódme - 44 . Były to zarówno pojedyncze określenia, jak i w większej liczbie (nieprzekraczającej jednak zgodnie z poleceniem pięciu skojarzeń). Pojawiające się odpowiedzi podzielić można na kilka grup - kategorii semantycznych organizujących postrzeganie gwary przez przeciętnego użytkownika polszczyzny. W pierwszej znajdują się asocjacje należące do kategorii niepowtarzalności, zgodnie z którymi gwara jest czymś wyjątkowym, wyróżniającym się (Specyficzna, wyjątkowa, unikalna, charakterystyczna; Swoista indywidualna niepowtarzalna; wyróżniająca cenna; Unikatowy, specyficzny; Z oryginalnościa). Owa - zdaje się pozytywnie oceniana - niepowtarzalność powiązana zostaje 
z kategorią terytorium (zasięgu terytorialnego). Ta cecha inaczej niż poprzednia pozbawiona jest nacechowania wartościującego, np. Lokalna, okoliczna; regionalna; zrozumiała dla mieszkańców danego regionu; kultura lokalna, regionalne potrawy, historia; Mowa regionalna; Że wsia; Ze slangiem rejonu; Powiedzonka i stowa zrozumiałe tylko przez określona grupę, region lub województwo. Gwara umożliwia identyfikację z regionem (tożsamość regionalna; Przynależność). Ze względu na przeciwstawienie 'swójobcy' (np. Z inna subkultura, z innym rejonem; swojsko godka - porozumiewanie się ludzi z danego regionu, aby zaznaczyć odrębność; rodzima) najbliższy teren zostaje utożsamiony z najbliższymi ankietowanym ludźmi (Wieś, babcia, tradycja; Z dziadkami; Rodzina; dom, sqsiadka) - wspólnotą, przez co ponownie powraca dodatnie wartościowanie (ż̇yta społeczność), ujawniające się m.in używaniem zaimka dzierżawczego, np. z rodzimymi stronami, nasza mowa na co dzień, nasza kulturą. Wspólnota tej samej mowy to także emocjonalne więzi ją łączące (Przynależność do grupy, swojskosc, rodzina, przyjaźń), a gwara to swego rodzaju spadek od minionych pokoleń (dziedzictwo, pamięć; tradycja, przywiązanie). Powyższe przykłady świadczą o funkcjonowaniu kategorii identyfikacji.

Zdarzają się także kategorie ambiwalentne. I tak egzotyczność (rozumiana jako odmienność, rzadkość) stanowi pas przejściowy między wartościowaniem pozytywnym a negatywnym. Z jednej bowiem strony gwara jest inna, niecodzienna, a przez to zabawna, śmieszna, ciekawa, zagadkowa, ale też trudna czy niezrozumiała. Podobnie kategoria dawności wskazuje, że gwara jest z jednej strony stara, są w niej archaizmy, kojarzy się z mowa starszych ludzi, a z drugiej strony jest wręcz starodawna; Gwara [gwarą - B.O.] mówiono kiedys i część uchowała się do dziś, głównie we wsi. Należy więc do przeszłości, a współcześnie posługiwać się nią mają tylko pewne (w niektórych środowiskach stygmatyzowane) grupy, np. Rolnicy, kgw [koło gospodyń wiejskich - B.O.], starsze osoby, przez co prorokuje się jej zanikanie. Negatywne skojarzenia są pochodną kategorii nieliterackości, stąd gwara jest potoczna; nieliteracka; ludowa; Prosta, nieelegancka, wiejska, używana bez zastanowienia. Opisuje się ją ponadto za pomocą określeń: Przeksztatcanie wyrazów; Niepoprawność gramatyczna, wiocha, wstyd; uproszczenie komunikacji; Mowa na skróty.

\section{Geografia gwar w świadomości ankietowanych}

W pytaniu ósmym należało wymienić do pięciu przykładów gwar. Najczęściej pojawiały się odpowiedzi o charakterze geograficznym: 20 razy wymieniono gwarę ślaską, 14 - kaszubska, 10 - góralska i po 9 - poznańska i wielkopolska. Pozostałe wskazania były mniej liczne. Można jednak mówić o pewnych ogólnych tendencjach. Wyobrażenie potoczne o gwarach kształtowane jest głównie przez kulturę popularną. Od lat funkcjonujący i rozpowszechniany przez mass media humor śląski (grupa kabaretowa Masztalscy czy Kabaret Młodych Panów, serial Święta wojna itd.) czy góralski (dowcipy o bacy i turystach, też zespół Golec uOrkiestra) umacniają w powszechnej opinii przekonanie o odmienności tych terenów. Co ciekawe, kultura góralska funkcjonuje właśnie pod taką wspólną, uogólniającą etykietą, a tylko pojedynczo zdarzyły się 
odpowiedzi wskazujące na odmienność poszczególnych grup górali (gwara podhalańska, gwara zakopiańska, gwara żywiecka).

Wymienienie gwary kaszubskiej świadczy o odporności wiedzy potocznej na współczesne zmiany zachodzące w ustaleniach naukowych. Tylko raz dało o sobie znać echo ustawy z 2005 roku o językach mniejszościowych i języku regionalnym, padła bowiem odpowiedź: [gwara] kaszubska - choć uznawana bardziej za język.

Kolejną tendencją jest oczywiście zwracanie uwagi na gwarę własnego terenu, stąd wymieniane po dziewięć razy gwara poznańska i gwara wielkopolska oraz jeden raz gwara poznańska/wielkopolska. Pojawiają się także odpowiedzi: gwara kujawska, gwara małopolska, gwara mazowiecka, gwara podlaska, gwara podkarpacka, gwara pomorska. Jak pokazują ostatnie przykłady za udzielonymi odpowiedziami nie musi stać faktyczna znajomość gwar polskich, lecz przekonanie, że każdy region (województwo?) ma własną gwarę, której nazwę można utworzyć od nazwy regionu (województwa?). Tu także widać używanie do nazywania gwar przymiotników od miast stołecznych danych regionów, np. gwara krakowska, gwara białostocka, gwara warszawska. Rodzi to uzasadnione pytania - czy ankietowani rozróżniają gwary miejskie i wiejskie oraz znają rozróżnienie gwara - dialekt. Innymi słowy, czy gwara krakowska to to samo co dialekt małopolski czy gwara miejska Krakowa?

Jak pokazują badania B. Cemborowskiego w potocznym odbiorze nie istnieje rozróżnienie gwara - dialekt czy gwara miejska - gwara wiejska (Cemborowski 2017, 53), stąd w ankiecie odpowiedzi typu: gwara uczniowska, gwara więzienna, gwara zawodowa, kmina. Ponownie więc widać pewne zacofanie w stosunku do współczesnego stanu wiedzy. Dawniej używana w literaturze gwara uczniowska, zastąpiona następnie przez np. socjolekt uczniowski, w potocznym użyciu - jak widać - nadal funkcjonuje.

\section{Stosunek do gwary}

W pytaniu dziewiątym ankietowani mogli wielokrotnie wybierać spośród 10 zdań testowych odpowiadających dziesięciu postawom wobec języka wyróżnionym za A. Markowskim (2006, 1646-1651), które zostały zaadaptowane do sytuacji gwarowych. Nikt nie wskazał puryzmu nacjonalistycznego, tradycjonalistycznego, egocentrycznego i postawy racjonalistycznej. Spośród pozostałych trzy wyróżniły się liczebnością. 24 głosy zebrał liberalizm językowy (zdanie: Akceptuję gwarę ze wszystkimi jej innowacjami językowymi, wariantami $i$ formami obocznymi) charakteryzujący się wysoką tolerancją w odniesieniu do wszelkich zmian językowych i dużą akceptacją wobec form obocznych i wariantywnych. Kolejna co do liczebności była postawa naturalna - 21 głosów (zdanie: Doceniam gware jako naturalny środek porozumiewania w pewnych środowiskach). Język jest tu traktowany jako „dobro naturalne”, środek, którego używa się w określony sposób, przyjęty w danym środowisku. Przestrzega się tu normy nieskodyfikowanej, naturalnej, ale mocno uświadamianej i przekazywanej zwyczajowo w grupie. Trzecią najczęstszą postawą był leseferyzm - 17 głosów (zdanie: Akceptuję gwarę, przecież mówi nia tak wiele osób) - czyli postawa akceptująca te zjawiska, które mają w języku dużą frekwencję. Pojedyncze osoby wybrały 
indyferentyzm językowy (5), puryzm elitarny (2), perfekcjonizm (1) i logizowanie w języku (1). Jak widać, ankietowanych cechują postawy tolerancji wobec gwary i nieoceniania innego sposobu mówienia.

\section{Pokoleniowe występowanie gwary}

W pytaniach od dziesiątego do trzynastego pytano o znajomość gwary wśród ankietowanych, ich rodziców, dziadków oraz w ich otoczeniu. Zgodnie z przewidywaniami (i ustaleniami innych badaczy - Grochola-Szczepanek 2008, 219) mniej badanych deklarowało używanie gwary przez siebie niż przez pokolenia starsze wobec siebie (por. tabela 2). I tak jednak zaskakuje, że aż ponad połowa ankietowanych stwierdziła, że mowi gwarą. Odsetek pozytywnych deklaracji jest zbliżony zarówno w przedziale do 25 roku życia, jak i powyżej6. Przyczyną tak wysokiego odsetka deklaracji może być faktyczne używanie tego kodu komunikacji, ale także brak umiejętności rozróżnienia środków gwarowych i innych substandardowych ${ }^{7}$, o czym była już mowa, oraz niesystemowe podejście do gwary. Przez ostatnie sformułowanie rozumiem takie sytuacje, gdy używa się kodu mieszanego (gwarowo-ogólnego) lub w wypowiedzi ogólnej pojawiają się interferencje gwarowe. Za taką interpretacją przemawiają odpowiedzi typu: używam słów zaczerpniętych z gwary; właściwie używam tylko części stownictwa.

Tabela 2. Deklaracja znajomości gwary

\begin{tabular}{|l|c|c|c|}
\hline \multicolumn{1}{|c|}{ Pytanie } & TAK (w \%) & NIE (w \%) & Inne $^{8}(\mathrm{w} \%)$ \\
\hline Czy mówisz gwarą? & 52 & 31 & 17 \\
\hline Czy Twoi rodzice mówią gwarą? & 59 & 28 & 13 \\
\hline Czy Twoi dziadkowie mówią gwarą? & 69 & 22 & 9 \\
\hline
\end{tabular}

Wśród osób z otoczenia ankietowanych, które mówią gwarą, wymieniani są członkowie rodziny (Żona, mama, rodzeństwo; Mąż, jego i moi rodzice; kuzynowie; ciocia), określone grupy wiekowe (ludzie powyżej 50 roku życia; Babcia, rodzeństwo babci; znajome babci; Dziadkowie), bliżsi i dalsi sąsiedzi (sąsiad, gospodarz, inni gospodarze też; mieszkańcy okolic), znajomi (Koleżanki, koledzy; przyjaciele; niektórzy znajomi), współpracownicy (szefostwo). Jest to bogata reprezentacja społeczna, nie dziwią więc

${ }^{6}$ Co zaskakuje w zestawieniu z wynikami A. Piechnik, wg których większość badanych uczniów (62\%) zadeklarowała, że nie używa gwary (Piechnik 2015, 237).

7 Podobne zjawisko, tj. synonimicznych użyć gwary i języka potocznego, zauważono wśród gimnazjalistów w Paleśnicy i Jastrzębi (Piechnik 2015, 236).

${ }^{8} \mathrm{~W}$ grupie tej mieszczą się odpowiedzi wskazujące na frekwencję używania gwary (wyjątkowo...; czasem; rzadko; po części; niekiedy; Nie zawsze ale zdarza sie), kontekst sytuacyjny (tak, ale tylko na wsi $i w$ rodzinie) lub ograniczenia systemowe, np. inteferencje leksykalne. 
odpowiedzi uogólniające: $W$ pracy, domu, a wcześniej $w$ szkole czy na dworze między rówieśnikami, jednak były i sa to raczej wyrazy plus krótkie zwroty aniżeli cała forma zdania; Wszyscy, tylko nie sa tego świadomi.

\section{Zakończenie}

Podsumowując, należy zwrócić uwagę na złożoność badania świadomości językowej w odniesieniu do gwary. Problemy stwarza już samo użycie słowa gwara, które przez językoznawców rozumiane jest jako termin, zaś wśród nieprofesjonalnych użytkowników języka funkcjonuje jako wyraz potoczny, o szerszym znaczeniu. Gwara w rozumieniu potocznym obejmuje nie tylko gwary ludowe, lecz także gwary miejskie, odmiany środowiskowe, niektóre środki substandardowe (potoczne) i regionalne. Rozbieżność tę należy brać pod uwagę przy układaniu pytań w ankiecie oraz przy analizowaniu pozyskanych za jej pomocą danych.

Jeśli chodzi o analizę danych $\mathrm{z}$ powiatu ostrowskiego, to świadomość istnienia gwary większa jest na wsi niż w dużym mieście. Dotyczy to także kwestii wyróżniania gwary miejskiej Ostrowa czy zauważania w mowie jego mieszkańców cech gwarowych. Częściej zauważają je mieszkańcy powiatu niż samego miasta. Wśród wskazywanych cech gwarowych Ostrowa i okolicy brakuje najwyrazistszych, poświadczonych dawniej przez badaczy, co świadczy o ich zaniku. Pojawiają się natomiast cechy ogólnowielkopolskie (często o statusie regionalizmów) lub szeroko znane w gwarach polskich. Gwara przeważnie wartościowana jest pozytywnie, choć rozpiętość oceny waha się między akceptacją a odrzuceniem.

\section{Literatura}

Cemborowski B. (2017), Funkcjonowanie gwar wielkopolskich w internecie. Przeglad wybranych form, [w:] Język w regionie - region w języku 2, pod red. B. Osowskiego, J. Kobus, P. Michalskiej-Góreckiej i A. Piotrowskiej-Wojaczyk, Poznań, s. 49-64.

Cygan S. (2011), Przejawy świadomości językowej mieszkańców wsi końca XX wieku na przykładzie Lasocina na Kielecczyźnie, Kielce.

Grochola-Szczepanek H. (2008), Stopień używania wyrazów ogólnopolskich i ich gwarowych odpowiedników - w ocenie młodych mieszkańców Spisza, „Język Polski” 88, s. 215-230.

Kąś J. (1994), Interferencja leksykalna słownictwa gwarowego i ogólnopolskiego (na przykładzie gwar orawskich), Kraków.

Kucała M. (1960), O słownictwie ludzi wyzbywajacych się gwary, „Biuletyn Polskiego Towarzystwa Językoznawczego" 19, s. 141-156.

Kucharzyk R. (2002), Język wsi z perspektywy autochtonów, [w:] Dialektologia jako dziedzina językoznawstwa i przedmiot dydaktyki. Księga jubileuszowa dedykowana profesorowi Karolowi Dejnie, red. S. Gala, Łódź, s. 277-286.

Kucharzyk R. (2011), Badania świadomości językowej mieszkańców wsi, „Poradnik Językowy” 4, s. $26-38$. 
Kurek H. (1995), Przemiany językowe wsi regionu krośnieńskiego. Studium socjolingwistyczne, Kraków.

Markowski A. (red.), (2006), Wielki słownik poprawnej polszczyzny PWN, t. 2: $Q-\dot{Z}$, Warszawa.

Nitsch K. (1968), Wybór polskich tekstów gwarowych, wyd. 3, Warszawa.

Nowak H., Skoczylas-Stawska H. (1990), Gwary ostrowskie, [w:] Ostrów Wielkopolski. Dzieje miasta i regionu, pod red. S. Nawrockiego, Poznań, s. 639-673.

Osowski B. (2019), Hiperyzmy - kiedy źródto nas mami, „Prace Filologiczne”, t. 73, s. 287-297.

Pawłowski E. (1967), Problem normy językowej w gwarach ludowych i języku ogólnonarodowym, „Biuletyn Polskiego Towarzystwa Językoznawczego” 25, s. 133-147.

Piechnik A. (2015), Gwara w świadomości gimnazjalistów wiejskich, [w:] Dialog pokoleń $w$ języku potocznym, w języku wsi i miasta, $w$ literaturze, $w$ publicystyce, $w$ tekstach kultury, pod red. E. Wierzbickiej-Piotrowicz, Warszawa, s. 235-241.

Piotrowicz A., Witaszek-Samborska M. (2009), Studia nad polszczyzna miejska Poznania, Poznań.

Sierociuk J. (2007), Socjologiczny kontekst badań języka mieszkańców wsi, „Gwary Dziš”, t. 4: Konteksty dialektologii, s. 325-336.

Sobierajski Z. (2001), Geolingwistyka i geoetnologia w atlasie regionalnym Welkopolski, „Gwary Dziś”, t. 1: Metodologia badań, s. 69-94.

Urbańczyk S. (1962), Zarys dialektologii polskiej, wyd. 2 zm. i rozszerz., Warszawa. 